\title{
USING PROCESS WRITING APPROACH (PWA) TO TEACH WRITING DESCRIPTIVE TEXT
}

\author{
FITRI NOVIA \\ Universitas Islam Ogan Komering llir Kayuagung, Indonesia \\ novia_f@uniski.ac.id \\ EVA SAPTARINA \\ Universitas Islam Ogan Komering llir Kayuagung, Indonesia \\ DOI: 10.29300/ling.v7i1.4075
}

Received: January 26th 2021

Accepted: March 23rd 2021

Published: July $13^{\text {th }} 2021$

\begin{abstract}
The research was aimed to find out whether or not there was a significant difference in students' writing performance from descriptive passage between learners who were practiced using the Process Writing Approach and those who were not. The design of that research was used quasi-experimental. Participants selected from X TKJ 3 were the experimental group and X TKJ 2 were the control group. Instruments of this study used written test. There were five topics about the descriptive text in which students chose one of the issues. A paired sample t-test and independent-sample t-test were used to investigate the data. The outcome acquired from the paired sample t-test confirmed that students' writing achievement increased in the descriptive text after using the process writing approach. Independent-samples t-test analysis revealed that $\mathrm{p}_{\text {value }}(0.008)$ was lower than $\alpha_{\text {valu }}(0.05)$. Further analysis indicated a significant difference in students' writing performance from a descriptive passage within learners who practiced using the Process Writing Approach.
\end{abstract}

Keywords: Process writing approach, writing, descriptive text

\section{INTRODUCTION}

Writing is a way of interaction in the form of written form. By hand, students can explore ideas, opinions, and knowledge during the process of learning. Hence, writing is considered a necessary skill. Anggeriyanti (2017) claimed that writing is an essential element that should be taught because writing is the fundamental language skill. Good writing is widely becoming recognized as a crucial skill for education, business, and employment (Susanti \& Novia, 2016). Hence, good writing is fundamental to communication that can be used to organize systematically thought so that students can communicate opinions, thoughts, and ideas effectively.

Unfortunately, writing is difficult and complicated for students when they need to finish the writing task. In doing a writing task, students find difficulties in accomplishing their composition. They have a poor vocabulary, low ability in applying grammar items, mechanics, organization, content, and style (Umamah \& Cahyono, 2020). It is in line with

How to cite this article: Novia, F., \& Saptarina, E. (2021). Using Process Writing Approach (PWA) to Teach Writing Descriptive Text. Linguists : Journal Of Linguistics and Language Teaching, 7(1), 1-9. doi:http://dx.doi.org/10.29300/ling.v7i1.4075 
Farooq et al. (2012) found that some students got problems doing English composition because the lack of vocabulary. They made mistakes in grammatical patterns and mechanics.

Furthermore, students get some problems in the beginning to write a paragraph based on the topic. It is a challenging task for students to organize their ideas well in a piece of writing. Regala-Flores \& Lopez (2019) reported that one of the daunting challenges L2 students face in writing is incorporating source information into their composition. Alshakhi (2018) stated that writing is the most challenging ability since pupils learn to focus more on essay and the grammatical rules. On the other side, Irawansyah (2016) explored that the students wrote shorter sentences to develop paragraphs; the supporting sentences did not support the main idea; the section lacked coherence and unity. Students found problems with their ability because they felt that they were not good writers and could not write well (Setyowati, 2017).

On the other hand, a descriptive text is one of the genres that should be learned. A descriptive text is a kind of genre that describes people, places, and things. It provides a detailed explanation of the characteristics of a person, location, and item. In developing descriptive paragraph, text construction requires the students to describe a specific thing, a person, or place. Even though it looks simple to tell something or someone, students still need more guidelines to compose the text. They should be concerned about the characteristic and element structure from this genre (Harlena, 2019). Further, identification and description are included in the descriptive text. Identification is the process of determining how to identify an object. The description is a way of conveying information about the object (Fitriani et al., 2019).

Nonetheless, writing descriptive text is not an easy task because students need to describe specific characteristics. According to Husna (2013), some students could not develop ideas and could not distinguish and represent an object in organizing thoughts. Students got low achievement in writing paragraphs about descriptive text since they lacked linguistic features, vocabulary, and grammatical rules (Haerazi \& Irawan, 2019). Therefore, Kirana et al., (2018) found that students had difficulties organizing ideas and content, coherence and mechanics in developing descriptive paragraphs (Kirana et al., 2018).

Process Writing Approach (PWA) can propose to help students composing descriptive text. According to Dokchandra (2018), PWA is a way that highlights the process of writing. Meanwhile, PWA is a writing process where students concentrate on their writing process, or what the authors do, rather than on the final product's appearance (Hartono et al., 2019). A 
process-based approach is an approach which helping students to organize their ideas in systematically stages to produce coherence and unity paragraph (Qomariah \& Permana, 2016).

PWA takes the students throughout the planning, drafting, polishing, and editing (Yeung, 2019). Rusinovci (2015) stated that prewriting activity ordinarily includes introducing ways to encourage the pupils to discover and take within each material. Before concentrating on a complete output, pupils demanded various sketches of the composed task. Discussion and feedback from readers would encourage students to improve their outlines. Rewriting and correction are necessary for typing, and editing is an on-going multi-level rule. Consequently, the outline rules involve producing opinions (prewriting), drafting the first design with stress toward content (determining interest), and drafts to improve concepts and communicate them. The composer, the topic, and the plan, and the varied script are the principal components for literature rule.

Additionally, thoughts, plans, and order fluency are characteristics in the process writing approach (Pour-Mohammadi et al., 2012). According to Xu \& Li (2018), students involve doing step by step by collecting concepts, planning, and editing. By using Process Writing Approach (PWA), writing should continually draft and revise towards the finished product (Jalaluddin, 2019). Thus, PWA gives students opportunities to organize, critique, and interpret something they become signed on (Akinwamide, 2012).

Furthermore, Agesta (2016) claims that PWA involves developing the rule of writing, prewriting, outlining, reviewing and editing, and displaying written text. Wulandari (2014) explained that PWA covering prewriting, drafting, reviewing, and editing helped students compose better writing and develop their critical thinking. PWA helped students understand writing descriptive text because it made them easier to explore ideas and knowledge to write their composition (Amalia et al., 2019). Through the writing process, students become more confident and discover how to generate ideas into their good written text (Sheir et al., 2015).

Moreover, Avc1 (2018) argued that students may use PWA to express their thoughts, gather knowledge, and develop their vocabulary and grammar. According to Nabhan (2016), PWA helped students improve their ability because it involved some step activities such as prewriting, writing the draft, polishing, editing, and publishing. Using PWA in writing class, students can generate information and knowledge to build sentences that supported main ideas. 
Therefore, Process Writing Approach (PWA) can apply to guide composing descriptive passage. Hence, this study assessed the process writing approach's impact on a descriptive manuscript's learners' writing performance. This study was aimed to examine the next research question: "Is there a significant difference in learners' writing performance regarding descriptive paragraphs within the students who practiced using the Process Writing Approach and this from those who are not?"

\section{METHOD}

\section{Respondents}

The participants were tenth grade students of SMK N 1 Kayuagung. The subjects were selected through a purposive sampling method. The criteria to determine the sample were as follows: the same English teacher taught them, and each class's total number was similar. Two groups of the subject decided by using the lottery, namely the experimental class (X TKJ 2) and the control class (X TKJ 3). Each group consisted of 31 students.

\section{Instruments}

A written test was used to collect data. There were five topics about the descriptive text in which students chose one of the issues. The students applied writing test twice, namely pretest (before treatment) and posttest (after treatment).

\section{Procedures}

This research's procedure consisted of giving a pre-test to students of both groups, for those experimental group (teaching writing descriptive text using process writing approach) and for those of the control group (no treatment) and giving students of both groups a post-test. Two inter- raters assessed the written test results using a rubric for writing descriptive text.

\section{Data analysis}

T-test was used to assess the data. In each category, data from the pre-test and posttest were analysed using a paired sample t-test. To compare data from the experimental and control groups, an independent sample t-test was used. 


\section{FINDINGS AND DISCUSSIONS}

From the computation of the paired sample t-test within the experimental class, the pretest score was 6.7, while the standard deviation was 1.0273. The average score from the posttest was 7.5, while the standard deviation was 1.2149. Since $p_{\text {value }}(0.000)$ was lower than $\dot{\alpha}_{\text {value }}(0.05)$; thus, there was progress in writing achievement of descriptive text after taught using the process writing approach. The experimental group students improved better after practicing typing descriptive topics by using the process writing approach to generate and organize their ideas in the prewriting stage. Before they wrote, students did brainstorming ideas through mind mapping. They listed the images as much as possible without thinking whether it was appropriate or not the topic. By doing prewriting stages, students could enlarge vocabulary and develop their ideas to write the first descriptive text draft. Students also could improve their linguistic features, grammar rules, and mechanics in revising and editing stages. As a result, students could organize their ideas well and compose better for their composition using PWA.

From the control group's paired sample statistics computation, the average score pretest was 5.8, while the standard deviation was 0.8707 . The average score from the posttest was 6.8 , while the standard deviation was 1.0521 . Therefore, the average rate from the posttest did better than the average rate from the pretest. Since $p_{\text {value }}(0.000)$ was lower than $\dot{\alpha}_{\text {value }}(0.05)$; thus, there was an improvement in writing achievement of descriptive text after taught without the process writing approach. Although the control group students did not guide through process writing, they improved since they kept practicing writing tasks.

From the calculation independent samples t-test, the finding t-obtained was 2.819, and the critical value of the t-table was 2.0003, $<<0.05$ at the significance level, and degree freedom (df) 60. It showed that $p_{\text {value }}(0.008)$ was lower than $\dot{\alpha}_{\text {value }}(0.05)$, it is indicated a significance difference in learners who were taught to write descriptive passages using process writing approach.

Using PWA, students trained to do prewriting, drafting, revising, and editing; thus, they explored their thoughts, ideas, opinions, and perceptions before writing a composition. Students applied mind mapping to discover ideas as many as possible without thinking inappropriate information in the prewriting stage. Students learned more about how to brainstorm and generate ideas that developed sentences to support sentences. After did brainstorming ideas, students wrote the first draft. This activity involved students in writing accurately and made them tended to have a writing habit. The next step, students did revise 
and editing, which built students' cooperative activities. By reading their classmate draft, students could correct the grammar rules and mechanics mistakes they wrote.

At last, students completed the final draft. This process built students' self-confidence naturally. As indicated by Wulandari (2014), the process writing approach changed students' behavior. They joined and involved discussion in having better ability in writing. By applying the process writing approach, students can read again and rewrite the draft and correct the mistakes (Sheir et al., 2015).

Through PWA, students were motivated to re-examine assignments, admit whatever peers and teachers tell concerning the script, rearrange ideas, select contextual words, use proper punctuation, and delete vague ideas. Hence, PWA could help students explore and organize thoughts, enrich vocabulary, and improve grammar rules and mechanics. It supported by (Avc1, 2018) PWA enabled students to express ideas, gather information, and improve their vocabulary and grammar. In summary, PWA increased students' ability to compose a descriptive paragraph. PWA can be used as an alternative strategy to encourage students to develop their writing abilities.

\section{CONCLUSION}

The current study indicated that $p_{\text {value }}(0.008)$ was lower than $\dot{\alpha}_{\text {value }}(0.05)$. Consequently, the work confirmed a significant difference in writing performance among the pupils taught by the process writing approach. With implementing PWA, students were triggering to explore ideas and develop thinking critically. Using PWA, students trained to do recursive steps, namely, prewriting, drafting, revising and editing, and producing final tasks. This process made students more focused on writing a better paragraph. PWA helped students organize their ideas, generate information, and develop vocabulary and grammar, and mechanics. In conclusion, students got better achievement in drafting a descriptive topic because they practiced using Process Writing Approach (PWA).

This finding suggests that an English teacher can apply the process writing approach to guide the composing descriptive passage. By implementing a process writing approach, learners can follow recursive stages to help students generate and organize their ideas for to create a well-written form. 


\section{REFERENCES}

Abas, I. H., \& Abd Aziz, N. H. (2018). Model of the writing process and strategies of EFL proficient student writers: A case study of Indonesian learners. Pertanika Journal of Social Sciences and Humanities, 26(3).

Agesta, S. (2016). Process genre approach: Breaking students' barriers in writing. International Conference on Education, 811-817.

Akinwamide, T. K. (2012). The influence of process approach on English as second language students' performances in essay writing. English Language Teaching, 5(3), 16-29. https://doi.org/10.5539/elt.v5n3p16

Alshakhi, A. (2018). Revisiting the writing assessment process at a Saudi English language institute: Problems and solutions. English Language Teaching, 12(1), 176. https://doi.org/10.5539/elt.v12n1p176

Amalia, Q., Anasy, Z., \& Dewi, R. (2019). The effect of using process approach on students' writing of descriptive text. ICEMS 2019, 1-8. https://doi.org/10.4108/eai.30-92019.2291190

Anggeriyanti, W. (2017). The correlation between students' reading habit and their writing skill. Proceedings International Conference on Teaching and Education (ICoTE), 1, 205-214. http://jurnal.untan.ac.id/index.php/icote/article/view/31134

Avc1, Ö. (2018). EFL learners ' insight into process oriented approach : In depth analysis of students perceptions on L2 writing skills, habits and Strategies. International Journal of Research in Teaching, Learning, Creativity \& Technology (IJRTL), 1(1), 1-25.

Dokchandra, D. (2018). The effects of process writing approach on performance of an overcrowded EFL writing class at a University in Thailand. KnE Social Sciences, 3(4), 161-173. https://doi.org/10.18502/kss.v3i4.1931

Farooq, M. S., Uzair-Ul-Hassan, M., \& Wahid, S. (2012). Opinion of second language learners about writing difficulties in English language. South Asian Studies, 27(1), 183.

Fitriani, F., Nur, R. H., Bustamin, B., Ali, S. M., \& Nurisman, N. (2019). Improving students' descriptive text writing by using writing in the here and now strategy at the tenth grade students of vocational high school. International Journal for Educational and Vocational Studies, 1(6), 632-636. https://doi.org/10.29103/ijevs.v1i6.1802

Haerazi, \& Irawan, L. A. (2019). Practicing genre-based language teaching model to improve students' achievement of writing skills. International Journal of English Teaching and Applied Linguistics, 4(1), 9-18.

Harlena, D. (2019). Collaborative writing strategy for teaching writing descriptive text. International Journal Of Scientific \& Technology Research, 8(10), 3316-3318. www.ijstr.org

Hartono, H., Anwar, C., \& Murtiningrum, A. (2019). Corrective feedbacks and grammar teaching in a situated teaching context of process-based writing. Register Journal, 12(1),

Linguists: Journal of Linguistics and Language Teaching

Vol. 7, No. 1, July 2021 
Husna, L. (2013). An analysis of students' writing skill in descriptive text at grade X1 IPA of MAN 2 Padang. Journal Ilmiah Pendidikan Scholastic, 1(1), 16-28.

Irawansyah, I. (2016). Genre based approach: A way to enhance studentsâ writing ability. English Education: Jurnal Tadris Bahasa Inggris IAIN Raden Intan, 9(1), 74-88. https://doi.org/10.24042/ee-jtbi.v9i1.420

Jalaluddin, I. (2019). Process approach in teaching of ESL writing: Teacher's assistance and its practicality in real classroom. Journal of Research, Policy \& Practice of Teachers \& Teacher Education, 9(2), 66-78. https://doi.org/10.37134/jrpptte.vo19.no2.6.2019

Kirana, E., Syarif, H., \& Anwar, D. (2018). Students' writing ability in descriptive texts and their problems of using appropriate adjective in SMP. International Conferences on Education, Social Sciences and Technology, 508-513. https://doi.org/10.29210/2018174

Nabhan, S. (2016). The process approach to improve students' writing ability in English Education Department University of PGRI Adi Buana Surabaya. Jembatan Merah, Jurnal Pengajaran Bahasa Dan Sastra, 13(June), 1-15.

Pour-Mohammadi, M., Abidin, M. J. Z., \& Fong, C. L. (2012). The effect of process writing practice on the writing quality of form one students: A case study. Asian Social Science, 8(3), 88-99. https://doi.org/10.5539/ass.v8n3p88

Qomariah, S. S., \& Permana, D. (2016). Process based approach towards students' creativity in writing English paragraph. Indonesian Journal of English Language Teaching and Applied Linguistics, 1(1), 37-47. www.ijeltal.org

Regala-Flores, E., \& Lopez, M. (2019). Self-reported summarizing and paraphrasing difficulties in L2 writing contexts: Some pedagogical interventions. Indonesian Journal of Applied Linguistics, 9(2), 286-296. https://doi.org/10.17509/ijal.v9i2.20219

Setyowati, L. \& Q. M. (2017). The eight graders writing attitude toward EFL writing in indonesian context. International Journal of Languages' Education, 5(3), 422-433. https://doi.org/10.18298/ijlet.2034

Sheir, A., Zahran, F., \& Koura, A. (2015). The effectiveness of process writing approach in developing EFL writing performance of ESP college students. Educations Sciences Journal, 1-23.

Susanti, R. T., \& Novia, F. (2016). Using POWER strategy to teach writing skill. Language and Education Journal, 1(2), 65-72.

Umamah, A., \& Cahyono, B. Y. (2020). Indonesian university students' self-regulated writing (SRW) strategies in writing expository essays. Indonesian Journal of Applied Linguistics, 10(1), 25-35. https://doi.org/10.17509/ijal.v10i1.24958

Wulandari, E. R. (2014). Process approach to improve students' writing skill for English major students. Media Prestasi Jurnal Ilmiah STKIP PGRI NGAWI, 13(1), 42-48. 
Xu, X., \& Li, X. (2018). Teaching academic writing through a process-genre approach: A pedagogical exploration of an EAP program in China. TESL-EJ, 22(2). 